\title{
VIRTUAL EXPERIMENT UNTUK MENINGKATKAN PEMAHAMAN SISWA PADA KONSEP GETARAN DAN GELOMBANG
}

\author{
Fahmi Yahya*, Hermansyah, Syarif Fitriyanto \\ Program Studi Pendidikan Fisika, Universitas Samawa \\ *Email: fyahyaadam@gmail.com
}

DOI: http://dx.doi.org/10.29303/jpft.v5i1.1141

\begin{abstract}
The experimental activities in physics learning are intended to build students' understanding of the concepts of physics. The limitations of experimental equipment have an impact on the low understanding of students' physics concepts. Virtual media can be used as an alternative experimental tool to improve students' conceptual understanding. This study aims to examine the effectiveness of virtual experiments in increasing students' understanding of the concepts of vibration and waves. Quasiexperimental research was conducted using the pretest and posttest control group design. The number of respondents was 40 students who were divided into the experimental group and the control group. The research data were analyzed by $N$-gain test to determine the level of increase in mastery of concepts using virtual experiments that have been used. The results showed that the achievement level of the experimental group was better than the control group. It can be concluded that virtual experiments are effective in increasing the understanding of students' physics concepts.
\end{abstract}

Keywords: Virtual Experiment, Concepts Understanding, Vibration And Waves Concepts

\section{PENDAHULUAN}

Eksperimen dalam pembelajaran IPA

khususnya fisika bermanfaat untuk mengkonstruk pemahaman siswa dalam memahami gejala alam, konsep, dan prinsip sains. Kegiatan ini sangat penting dilakukan oleh siswa untuk membuktikan konsepkonsep dari teori-teori yang telah dipelajari. Fisika pada hakekatnya melibatkan dimensi produk berupa kumpulan teori yang telah teruji kebenarannya dan dimensi produk berupa serangkaian kegiatan yang harus dilakukan untuk memperoleh pengetahuan dan gejala-gejala alam yang kita kenal sebagai metode ilmiah (Sund \& Trowbridge, 1973). Suparno (2007) menegaskan pembelajaran fisika hendaknya dilaksanakan secara inkuiri ilmiah untuk menumbuhkan kemampuan berpikir, bekerja dan bersikap ilmiah serta mengkomunikasikannya sebagai aspek penting kecakapan hidup. Mengacu pada hal tersebut, pembelajaran fisika hendaknya berorientasi pada keterampilan proses dengan melakukan eksperimen sehingga siswa mendapatkan kesempatan seluas-luasnya untuk berinteraksi dengan obyek konkrit sampai dengan penemuan konsep.

Berdasarkan hasil observasi di beberapa Sekolah Menengah Pertama di Sumbawa, ditemukan bahwa proses pembelajaran fisika yang berlangsung dalam kelas selama ini masih didominasi oleh model pembelajaran langsung dengan metode ceramah dan demonstrasi sederhana. Hal tersebut karena terbatasnya fasilitas laboratorium fisika yang kerap dihadapi oleh sekolah, baik dari segi jumlah maupun kualitas. Kualitas alat laboratorium yang kurang menyebabkan rendahnya kualitas pengukuran sehingga hasil pengukuran kurang akurat. Hasil pengukuran yang kurang akurat tidak dapat digunakan untuk mengkonstruk pemahaman konsep siswa sebagaimana mestinya. Keterbatasanketerbatasan tersebut berdampak terhadap rendahnya tingkat pemahaman konsep fisika siswa.

Untuk mengatasi permasalahan tersebut, maka dibutuhkan sebuah inovasi pada media pembelajaran agar kegiatan eksperimen fisika tetap dapat dilaksanakan seperti seharusnya. Salah satu alternatif yang 
dapat dilakukan adalah dengan memanfaatkan perkembangan teknologi informasi komputer. Salah satu media pembelajaran yang penggunaannya memanfaatkan teknologi komputer yaitu program media virtual seperti laboratorium virtual, multimedia interaktif, dan simulasi interaktif. Pemanfaatan media virtual dalam proses pembelajaran untuk melakukan praktikum berbasis komputer dinamakan dengan virtual experiment. Sarini (2012) mengemukakan bahwa virtual experiment merupakan eksperimen yang menggunakan simulasi pembelajaran berupa software dan komputer dalam menjalankan fungsi-fungsi penting laboratorium sebagaimana layaknya eksperimen biasa (real experiment). Sherwood dalam Manurung \& Rustaman (2010) mengemukakan beberapa keunggulan pemanfaatan virtual experiment dalam pembelajaran fisika yaitu mempermudah siswa dalam memperoleh informasi dan mempermudah guru dalam menyampaikan permasalahan yang kontekstual kepada siswa, serta dapat dilihat secara visual dan dinamis sehingga memudahkan siswa dalam memahami konsep, terutama konsep-konsep yang bersifat abstrak dan bersifat proses.

Pentingnya penggunaan komputer sebagai alat bantu untuk menjalankan media virtual tidak lepas dari pemanfaatan komputer dalam mensimulasikan materimateri yang sulit disajikan, terutama mengenai fenomena fisis yang bersifat abstrak. Selain keterbatasan yang telah disebutkan, Manurung \& Rustaman (2010) mengemukakan bahwa tidak semua eksperimen dapat dilakukan secara nyata di laboratorium, bukan hanya karena peralatannya yang terbatas, tetapi karakteristik materi fisika itu sendiri yang melibatkan proses dan konsep abstrak yang tidak dapat diamati secara kasat mata. Hal ini yang menjadikan media virtual merupakan solusi yang tepat dalam melaksanakan experiment untuk meningkatkan pemahaman konsep fisika siswa, khususnya pada materi getaran dan gelombang yang memiliki beberapa konsep yang cukup sulit untuk divisualkan melalui media riil.

\section{METODE PENELITIAN}

Penelitian ini bertujuan untuk menguji efektivitas dari penggunaan media virtual sebagai alat bantu experiment dalam meningkatkan pemahaman konsep fisika siswa. Penelitian eksperimen semu ini dilakukan di salah satu Sekolah Menengah Pertama kelas VIII yang terdapat di Kabupaten Sumbawa dengan jumlah responden kelompok kontrol sebanyak 20 orang siswa dan kelompok eksperimen sebanyak 20 orang siswa. Kelompok eksperimen diberikan perlakuan dengan menggunakan media virtual, sedangkan kelompok kontrol diberikan perlakuan konvensional. Desain yang digunakan dalam penelitian ini adalah pretest posttest control group. Materi penelitian ini adalah getaran dan gelombang. Pengumpulan data penelitian menggunakan instrumen soal berupa pilihan ganda sebanyak 20 butir soal dengan empat alternatif pilihan jawaban yang telah divalidasi sebelumnya oleh beberapa ahli. Data penelitian dianalisis menggunakan uji $\mathrm{N}$-gain untuk mengetahui peningkatan pemahaman konsep siswa setelah diberikan perlakuan menggunakan media virtual. Data diinterpretasikan berdasarkan kategori tinggi ( $\mathrm{N}$-gain $>70.0$ ), sedang $(70.0>\mathrm{N}$-gain $>30.0)$, dan rendah (30.0>N-gain) (Hake, 1999).

\section{HASIL DAN PEMBAHASAN}

Analisis pemahaman konsep siswa dilakukan dengan mengimplementasikan media virtual dalam melakukan experiment yang melibatkan kelompok eksperimen dan kelompok kontrol. Perbandingan tingkat pemahaman konsep siswa pada Gambar 1 memperlihatkan bahwa kelompok eksperimen lebih baik dibandingkan dengan 
kelompok kontrol. Hal ini terlihat dari perolehan skor N-gain dari kelompok eksperimen sebesar 60,00 \% dan kelompok kontrol sebesar $17,00 \%$. Peningkatan pemahaman konsep yang terjadi pada kelompok eksperimen masuk dalam kategori sedang, sedangkan kelompok kontrol masuk dalam kategori rendah.

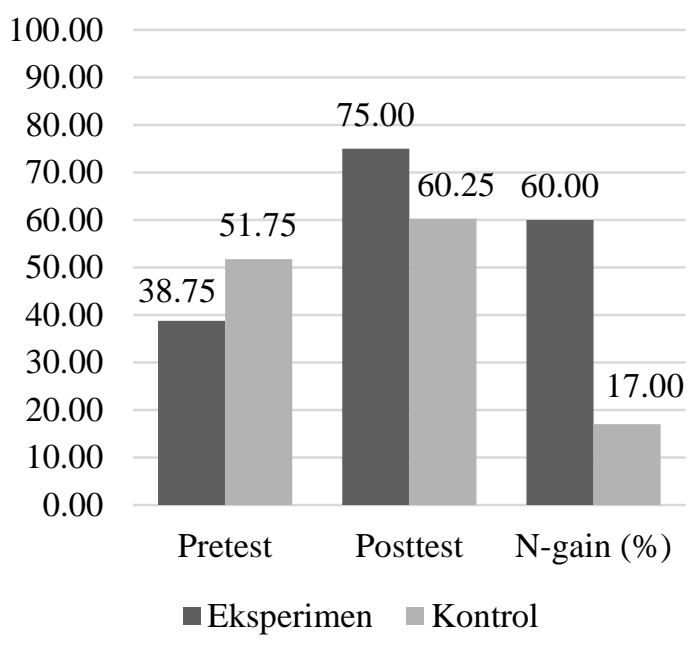

Gambar 1. Perbandingan Pemahaman Konsep Siswa

Pemahaman konsep kelompok eksperimen lebih baik dibandingkan dengan kelompok kontrol karena dalam proses pembelajaran kelompok eksperimen diberikan perlakuan dengan menggunakan media virtual. Melalui penggunaan media virtual, siswa dapat melaksanakan rangkaian experiment tentang materi getaran dan gelombang. Rangkaian experiment yang dilakukan memberikan kesempatan pada siswa untuk belajar secara mandiri sehingga mereka mampu mengkonstruk pemahamannya tentang konsep-konsep getaran dan gelombang. Media virtual terdiri dari program komputer yang memberikan peluang bagi siswa untuk belajar mandiri dan menemukan konsep fisika sehingga pembelajaran lebih bermakna, dapat meningkatkan kemampuan siswa dalam memecahkan masalah dan meningkatkan minat belajar karena penggunaan media virtual dalam pembelajaran fisika adalah sesuatu yang baru bagi siswa (Hermansyah et al. 2015; Hermansyah et al. 2018).

Lala et al. (2010) menyatakan bahwa penggunaan media virtua dapat mempermudah dalam mempelajari teori melalui visualisasi prinsip dengan cara yang sederhana. Yahya \& Fitriyanto (2016) menyatakan bahwa penggunaan simulasi interaktif sebagai salah satu media virtual dalam pembelajaran terbukti mampu meningkatkan keterampilan berpikir siswa karena dapat memvisualisasikan konsepkonsep abstrak dan menyajikan proses fisis dengan lebih lengkap. Hasil Penelitian Ratna \& Gunawan (2018) juga menunjukkan pengaruh yang positif dari penggunaan simulasi komputer terhadap keterampilan berpikir kritis siswa.

Efektifnya penggunaan media virtual ini sebagai bukti bahwa media virtual dapat mengatasi keterbatasan akan minimnya keberadaan alat-alat percobaan khususnya pada materi getaran dan gelombang. Tuysuz (2010) yang menyatakan bahwa pada saat pelaksanaan praktikum dengan menggunakan laboratorium virtual lebih efektif, menarik dan lebih bermanfaat serta dapat memungkinkan peserta didik untuk mengulang percobaan dibanding dengan kelompok yang menggunakan laboratorium riil karena tidak semua peserta didik aktif dalam proses eksperimen di laboratorium riil.

Peneliti lainnya juga menemukan bahwa penggunaan simulasi komputer sebagai laboratorium virtual terbukti dapat meningkatkan penguasaan konsep fisika peserta didik (Gunawan et al. 2018a), maupun kreativitas peserta didik, baik pada aspek verbal, figural, maupun numerik (Gunawan et al. 2018b; 2018c).

Selain ditinjau secara umum, pemahaman konsep siswa juga ditinjau berdasarkan per sub materi. Terdapat dua sub materi dalam penelitian ini yaitu getaran dan gelombang seperti yang ditampilkan pada 
Gambar 2. Berdasarkan gambar tersebut, terlihat bahwa perolehan skor $\mathrm{N}$-gain kelompok eksperimen lebih tinggi dibandingkan dengan kelompok kontrol pada kedua sub materi dengan kategori sedang.

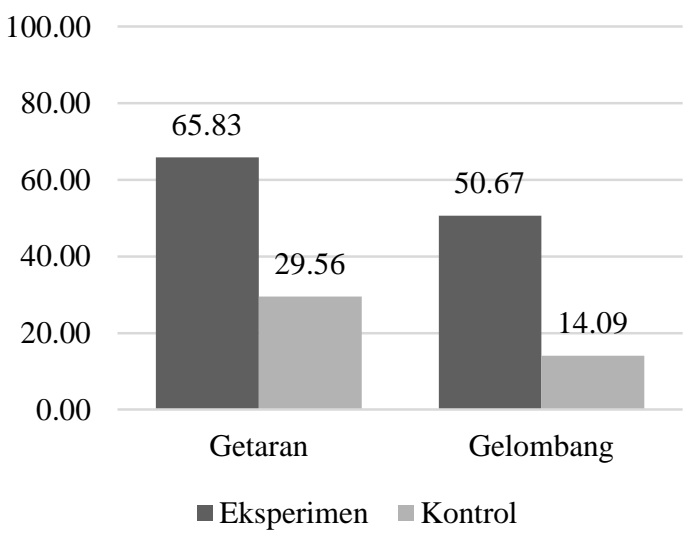

Gambar 2. Perbandingan Peningkatan Pemahaman Konsep Siswa Pada Tiap SubMateri

Hal ini membuktikan bahwa penggunaan media virtual dalam melakukan experiment dapat meningkatkan pemahaman konsep siswa dengan lebih baik. Keakuratan hasil pengukuran selama melakukan virtual experiment memungkinkan siswa dapat mengkonstruk pemahaman mereka berdasarkan pemahaman-pemahaman yang telah diperoleh. Hermansyah et al. (2017) dalam penelitiannya menyatakan bahwa tingginya pencapaian penguasaan konsep kelompok eksperimen pada setiap sub materi kalor disebabkan karena pelaksanaan pembelajaran menggunakan laboratorium virtual yang menyajikan informasi-informasi melalui media teks, gambar, video, animasi, dan simulasi yang mendukung setiap sub materi serta didukung dengan kegiatankegiatan ilmiah untuk melatih peserta didik dalam mengkonstruk pemahaman mereka akan konsep-konsep fisika secara mandiri.

Penggunaan media virtual mempermudah siswa dalam memahami konsep-konsep pada materi getaran dan gelombang melalui simulasi, animasi, dan gambar-gambar yang terdapat didalamnya.
Selain itu, penggunaan media virtual juga mampu membuat siswa termotivasi untuk lebih giat lagi dalam mempelajari materi ini melalui simulasi dan animasi yang terdapat di dalamnya. Proses pembelajaran akan berhasil jika adanya faktor yang dapat memotivasi siswa dalam belajar selain dari diri sendiri seperti lingkungan belajar baik guru maupun sumber belajarnya. Holden \& Gamor (2010) menyatakan bahwa laboratorium virtual sebagai salah satu dari media virtual merupakan sebuah media yang dapat digunakan untuk menyampaikan pesan atau informasi, memotivasi, membuat siswa lebih memperhatikan, dan menghasilkan pembelajaran yang mengesankan.

Peningkatan pemahaman konsep siswa pada sub materi getaran lebih tinggi dibanding pada sub materi gelombang untuk kedua kelompok. Hal ini karena soal-soal pada sub materi getaran lebih didominasi oleh soal-soal yang hanya bersifat konsep dibanding sub materi gelombang yang lebih didominasi oleh soal-soal matematis. Soalsoal yang berhubungan dengan konsep lebih mudah dijawab oleh siswa dibandingkan dengan soal-soal yang membutuhkan penyelsaian dengan cara matematis karena visualisasi konsep-konsep getaran yang ditampilkan dalam media virtual mempermudah siswa dalam memahaminya. Gambaran visual dapat mengkomunikasikan pesan dengan cepat dan nyata, oleh karena itu dapat mempercepat pemahaman pesan secara lebih komprehensif. Pesan visual lebih efektif dan efisien dalam arti penyajian visual dapat membuat siswa lebih berkonsentrasi (Diana et al. 2018). Sejalan dengan hal itu Hermansyah et al. (2019) menyatakan bahwa kegiatan ilmiah yang dilakukan dengan menggunakan media virtual dapat membantu siswa memahami konsep kalor melalui visualisasi konsep abstraknya. Gunawan et al. (2017) mengungkapkan bahwa media virtual adalah alternatif untuk peralatan eksperimen fisika 
yang terbatas dan membantu memvisualisasikan konsep abstrak. Hermansyah et al. (2017) mengemukakan bahwa penemuan konsep-konsep yang dilakukan menjadi lebih mudah dilakukan menggunakan laboratorium virtual karena visualisasi konsep yang disajikan pada materi yang menyerupai bentuk rillnya.

\section{PENUTUP}

Implementasi media virtual dalam experiment fisika khususnya pada materi getaran dan gelombang dapat meningkatkan pemahaman konsep siswa. Peningkatan pemahaman konsep fisika siswa kelompok eksperimen lebih baik dibandingkan dengan kelompok kontrol baik pada sub materi getaran maupun gelombang.

\section{REFERENSI}

Diana, N., Walidain, S. N., \& Rahman, A. H. 2018. Integrasi Learning Management System (LMS) dan Simulasi PhET pada Pembelajaran Fisika Terhadap Keterampilan Proses Sains. QUARK: Jurnal Inovasi Pembelajaran Fisika Dan Teknologi, 1(1), 36-40.

Gunawan, G., Harjono, A., Sahidu, H., \& Herayanti, L. 2017. Virtual Laboratory of Electricity Concept to Improve Prospective Physics Teachers Creativity. Jurnal Pendidikan Fisika Indonesia, 13(2), 102-111.

Gunawan, Nisrina, N., Suranti, N. M. Y., Herayanti, L., \& Rahmatiah, R. 2018a. Virtual Laboratory to Improve Students' Conceptual Understanding in Physics Learning. Journal of Physics: Conference Series. 1108 (1) p. 012049.

Gunawan, Suranti, N. M. Y., Nisrina, N., Herayanti, L., \& Rahmatiah, R. 2018b. The effect of virtual lab and gender toward students' creativity of physics in senior high school. In Journal of Physics: Conference Series 1108 (1) p. 012043.
Gunawan, Harjono, A., Sahidu, H., \& Nisrina, N. 2018c. Improving students' creativity using cooperative learning with virtual media on static fluida concept. Journal of Physics: Conference Series, 1006 (1), 012016.

Hake R 1999 Analyzing Change/Gain Score (Indiana: Indiana University).

Hermansyah, H., Gunawan, G., \& Harjono, A. 2017. Pengaruh Penggunaan Laboratoium Virtual Dalam Pembelajaran Inkuiri Terbimbing Terhadap Penguasaan Konsep Kalor Peserta Didik. Jurnal Pendidikan Fisika dan Teknologi, 3(2), 249-256.

Hermansyah, H., Gunawan, G., \& Harjono, A. 2018. The Effect of Using Virtual Laboratory in Guided Inquiry Learning on Cognitive Learning Outcomes of Physics. IOSR Journal of Research \& Method in Education (IOSR-JRME), 8(1), 15-20.

Hermansyah, H., Gunawan, \& Herayanti, L. 2015. Pengaruh penggunaan laboratorium virtual terhadap penguasaan konsep dan kemampuan berpikir kreatif siswa pada materi getaran dan gelombang. Jurnal Pendidikan Fisika dan Teknologi, 1(2), 97-102.

Hermansyah, H., Gunawan, Harjono, A., \& Adawiyah, R. 2019. Guided inquiry model with virtual labs to improve students' understanding on heat concept. Journal of Physics: Conference Series. 1153(1), 012116. IOP Publishing.

Holden J T \& Gamor K I. 2010. An Instructional Media Selection Guide for Distance Learning (2nd Ed.) (United States of America: United States Distance Learning Association).

Lala, Z. H. A. O., Chusheng, L. I. U., \& Junxia, Y. A. N. 2010. A Virtual Experiment Showing Single Particle Motion on A Linearly Vibrating Screen-Deck. Mining Science and Technology (China), 20(2), 276-280. 
Manurung, S., \& Rustaman, N. Y. 2010. Hands and minds activity dalam pembelajaran fisika kuantum untuk calon guru. In Prosiding Seminar Nasional Fisika.

Mashami, R. A., \& Gunawan. 2018. The Influence of Sub-Microscopic Media Animation on Students' Critical Thinking Skills Based on Gender. In Journal of Physics: Conference Series. 1108 (1) p. 012106.

Sarini, P. 2012. Pengaruh Virtual Experiment Terhadap Hasil Belajar Fisika Ditinjau dari Motivasi Belajar Siswa SMA Negeri 1 Singaraja. Jurnal Pendidikan dan Pembelajaran IPA Indonesia, 2(2).

Sund, R. B., \& Trowbridge, L. W. 1973. Teaching science by inquiry in the secondary school. Merrill Publishing Company.

Suparno, P. 1997. Filsafat Konstruktivisme dalam Pendidikan. Yogyakarta: Kanisius.

Tuysuz, C. 2010. The Effect of the Virtual Laboratory on Students' Achievement and Attitude in Chemistry. International Online Journal of Educational Sciences. 2(1), 37-53.

Yahya, F., \& Fitriyanto, S. 2018. Pengaruh Model Pembelajaran Berbasis Masalah Berbantuan Simulasi Interaktif Terhadap Keterampilan Generik Sains Siswa SMA Pada Materi Elastisitas. Jurnal Pendidikan Fisika dan Teknologi, 2(3), 136-141. 